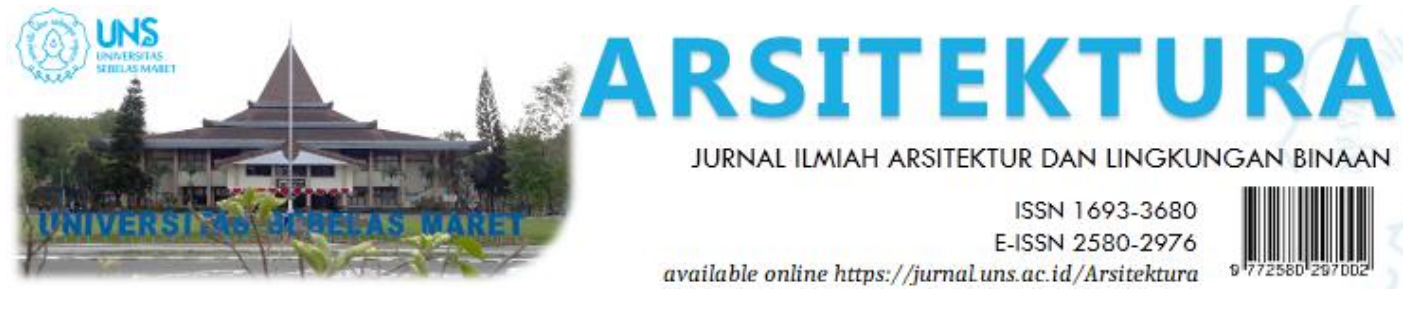

Volume 18 Issue 2 October 2020, pages:175-184

\title{
Karakter Fisik Bangunan di Daerah Perbatasan Antar Negara, Studi Kasus: Aruk, Kalimantan Barat
}

\section{Physical Character of Building in the Border Area, Case Study : Aruk. West Kalimantan}

\author{
Lestari $^{1 *}$, Syaiful Muazir ${ }^{2}$, M. Ridha Alhamdani ${ }^{3}$, M. Nurhamsyah ${ }^{4}$ \\ Jurusan Arsitektur, Fa kultas Teknik, Universitas Ta njungpura ${ }^{1^{*}}$ \\ lestari@teknik.untan.ac.id \\ Jurusan Arsitektur, Fakultas Teknik, Universitas Tanjungpura ${ }^{2}$ \\ Jurusan Arsitektur, Fa kultas Teknik, Universitas Ta njungpura ${ }^{3}$ \\ Juru san Arsitektur, Fakultas Teknik, Universitas Tanjungpura ${ }^{4}$
}

DOI: https://doi.org/10.20961/arst.v18i2.41976

Received: June 5, 2020 Revised: July 20,2020 Accepted: July 21, 2020 Available online: October 31, 2020

\begin{abstract}
Aruk is part of Sebunga Village, Sajingan Besar District, Sambas Regency, west-Kalimantan. The Aruk region is directly adjacent to the country of Malaysia and developed into a Pos Lintas Batas Negara $(P L B N)$. The existence of PLBNprovides easy access that affectsnot only the economic and social culture, but also has an impacton the physical changes of buildings in this area. This research was conducted to recognize the physical characteristics of buildings, especially residential buildings located in the Aruk border area. 74 selected buildings were collected through observation which was strengthened by interviews with users. The variables in this study are the function, use of materials and visual form of the building's appearance. Data were analyzed to see the closeness of building characteristics, especially with the year of establishment so as to conclude the character of residential buildings in the se locations. The results of the analysis show that buildings that builtearlier periode in the Aruk use material that are easily found around locations, especiallywood, and have a more complex appearance than the buildings after. These characteristics tend to change in line with the development of this area and increasinglyeasy access to the region.
\end{abstract}

Keywords: characteristic, building, border, Aruk.

\section{PENDAHULUAN}

Pembangunan infrastruktur di daerah perbatasan merupakan salah satu upaya yang dilakukan oleh pemerintah untuk mempercepat laju pertumbuhan dan perkembangan di daerah tersebut. Pembangunan infrastruktur dapat mempengaruhi banyak aspek diantaranya adalah aspek ekonomi, budaya, sosial maupun perubahan pada fisik kawasan. Pembangunan infrastruktur secara signifikan mempengaruhi pertumbuhan ekonomi yang ada (Lestari \& Suhadak, 2019), karena kesenjangan pembangunan infrastruktur cenderung juga diikuti dengan kesenjangan ekonomi (Sukwika, 2018). Upaya untuk menjadikan daerah perbatasan sebagai beranda depan diwujudkan oleh pemerintah dengan melakukan percepatan pembangunan infrastuktur. 
Aruk merupakan salah satu dusun di Desa Sebunga, Kecamatan Sajingan Besar, Kabupaten Sambas, Kalimantan Barat. Desa Sebunga memiliki luas $352,26 \mathrm{~m}^{2}$ dan merupakan desa terluas ke dua setelah Desa Sungai Bening di Kecamatan Sajingan Besar (Badan Pusat Statistik, 2019). Sebagai salah satu dusun dari 3 dusun yang berada di Desa Sebunga, Aruk memiliki wilayah yang berbatasan langsung dengan negara tetangga Malaysia dan dikembangkan menjadi kawasan pos lintas batas negara (PLBN). PLBN memiliki fungsi menyelenggarakan kegiatan dan mendukung aktivitas lintas perbatasan dua negara. Pembangunan infrastruktur PLBN Aruk telah dimulai sejak tahun 2015 dan sudah diresmikan sekaligus memulai beroperasi pada tahun 2017.

Pembangunan PLBN Aruk telah memberikan dampak positif terhadap pertumbuhan sektor sosial ekonomi di daerah tersebut (Firdaus, 2019). Pada tahun 2015, Desa Sebunga masih merupakan desa dengan kategori tertinggal. Ketertinggalan tersebut dilihat dari pembangunan sosial masyarakat yang masih dinilai rendah, dilihat dari kualitas sumberdaya manusia yang ada (Mufizar et al., 2012). Hal ini disebabkan terbatasnya sarana dan prasarana pendidikan, kesehatan, serta terbatasnya pusat pertumbuhan ekonomi masyarakat. Namun, keberadaan PLBN memberi pengaruh terhadap berkembangnya aktivitas ekonomi di daerah tersebut yang di tandai dengan munculnya berbagai kegiatan ekonomi yang menunjang aktivitas PLBN. Aktivitas ekonomi juga memberi dampak terhadap pembangunan sosial budaya masyarakat.

Pertumbuhan ekonomi, sosial dan budaya juga memberikan dampak terhadap perubahan kondisi fisik kawasan. Perkembangan aktivitas ekonomi dapat mempengaruhi pola penggunaan lahan (Dhika \& Pm, 2012). Selain itu, pertumbuhan ekonomi juga dapat memberikan pengaruh terhadap pertumbuhan penduduk dan perubahan bangunan asli (Suartha \& Yasa, 2017). Perubahan bangunan dapat mencakup perubahan tampilan dan karakteristiknya (Murti \& Wijaya, 2012). Pertumbuhan ekonomi di daerah perbatasan Aruk juga dapat berdampak pada perubahan kondisi fisik kawasan di daerah tersebut. Munculnya berbagai aktivitas ekonomi yang menunjang kegiatan di sekitar kawasan PLBN memunculkan bangunan-bangunan dengan fungsi komersil. Bangunan dengan fungsi penginapan sementara juga sudah mulai muncul di sekitar perbatasan Aruk.

Munculnya berbagai bangunan untuk menunjang aktivitas ekonomi dan sosial budaya dapat mempengaruhi identitas bangunan pada suatu kawasan. Identitas bangunan dapat mengalami perubahan karena berbagai faktor diantaranya adalah perubahan jumlah penghuni rumah, faktor ekonomi, serta kurangnya pengetahuan masyarakat dalam mempertahankan identitas (Arifin, 2010). Karakter bangunan sebagai identitas dari bangunan dapat ditunjukkan dari berbagai faktor diantaranya adalah bentuk bangunan dan bahan bangunan (Torabi \& Brahman, 2013). Bentuk bangunan merupakan salah satu faktor yang memiliki pengaruh besar terhadap karakteristik arsitektur (Januastuti \& Artiningrum, 2018).

Kondisi fisik yang menggambarkan kekhasan suatu daerah menjadi modal penting dalam memahami suatu kawasan. Mengenali kondisi fisik selain menggambarkan kondisi setempat juga dapat menggambarkan ciri dan identitas lokasi tersebut. Arsitekur bangunan merupakan identitas yang dimiliki oleh suatu daerah (Jones \& Svejenova, 2017) yang menggambarkan nilai ciri khas yang dimiliki oleh daerah tersebut. Identitas bangunan di daerah perbatasan seperti perbatasan Aruk menjadi penting mengingat daerah tersebut berada di antara dua negara. Kondisi bangunan dan kawasan di daerah perbatasan dapat mengalami perubahan dengan cepat seiring berkembangnya kondisi sosial ekonomi di daerah tersebut.

Suatu kawasan dapat dikenali melalui karakter fisik yang terdapat pada bangunan di daerah tersebut. Karakter bangunan memberikan nilai tersendiri pada kawasan seperti bentuk bangunan, penggunaan material yang menunjukkan kekhasan dan menjadi nilai pembeda bangunan-bangunan yang berada di daerah tersebut dengan daerah lain. Arsitektur bangunan merupakan demonstrasi dari identitas yang mencerminkan tempat, waktu, dan budaya suatu daerah (Salman, 2016). Studi mengenai bangunan setempat memiliki peran dalam mengenali identitas kawasan yang selalu 
dapat mengalami perubahan (Heath, 2015). Penelitian ini dilakukan untuk mengenali karakter fisik bangunan khususnya bangunan rumah tinggal yang terdapat di daerah perbatasan Aruk sehingga dapat memberikan gambaran identitas setempat. Karakter fisik dari bangunan menunjukkan ciri-ciri khusus yang melekat pada bangunan di kawasan tersebut. Keunikan dan nilai-nilai lokalitas dapat dijadikan sebagai pendekatan dalam perancangan bangunan (Hidayatun et al., 2016) sehingga kekuatan desain dapat responsif terhadap kondisi dan nilai kekhasan setempat.

\section{METODE}

Penelitian ini dilakukan di wilayah Dusun Aruk, Desa Sebunga, Kecamatan Sajingan Besar, Kabupaten Sambas, Kalimantan Barat (Gambar 1). Penelitian ini difokuskan pada bangunan-bangunan yang dibangun oleh masyarakat karena merupakan bangunan yang muncul pertama kali sehingga dapat mencirikan keadaan setempat. Bangunan-bangunan tersebut juga menggambarkan kondisi kemampuan membangun dari masyarakat di lokasi objek penelitian. Bangunan yang dibangun oleh masyarakat setempat secara mandiri sebagian besar berupa bangunan rumah tinggal. Penelitian untuk mengidentfikasi karakter fisik bangunan tersebut dilakukan dengan metode survey ke objek-objek bangunan di lokasi penelitian. Penelitian menggunakan teknik sampling dengan pertimbangan pemilihan sample berdasarkan karateristik tipe yang ditemukan sehingga dapat merumuskan karakteristik bangunan rumah tinggal pada kawasan tersebut. Sebanyak 74 bangunan terpilih dikumpulkan datanya melalui observasi yang diperkuat dengan wawancara dengan pengguna. Variabel utama dalam penelitian ini meliputi fungsi, penggunaan material dan bentuk visual tampilan bangunan. Penggunaan material meliputi material konstruksi utama bangunan, lantai serta dinding. Bentuk tampilan bangunan yang diteliti meliputi bentuk atap, dinding, pintu dan jendela serta lubang angin. Data tersebut kemudian dikelompokkan dan dikategorisasikan berdasarkan kesamaan karakter yang terlihat. Kategori karakter bangunan kemudian dilihat kedekatannya terhadap data lain khususnya data tahun berdirinya bangunan sehingga dapat menyimpulkan karakter bangunan rumah tinggal di lokasi tersebut.

Adapun proses penelitian yang dilakukan sebagai berikut:

1. Pengumpulan data sekunder berupa jumlah bangunan rumah serta peta dan batasan lokasi penelitian melalui melalui dokumendokumen yang telah tersedia di pihak-pihak terkait khususnya pemerintahan setempat.

2. Pengumpulan data primer melalui pemetaan langsung kawasan penelitian (menggunakan foto satelit) dan observasi pendahuluan untuk memetakan persebaran dan tipe bangunan rumah tinggal

3. Menentukan jumlah dan bangunan sample berdasarkan data yang telah dikumpulkan sebelumnya.

4. Pengumpulan data primer melalui observasi langsung pada bangunan dengan dukungan wawancara terhadap pengguna bangunan

5. Melakukan analisis dan menyimpulkan temuan berupa karakter bangunan rumah tinggal di lokasi tersebut.

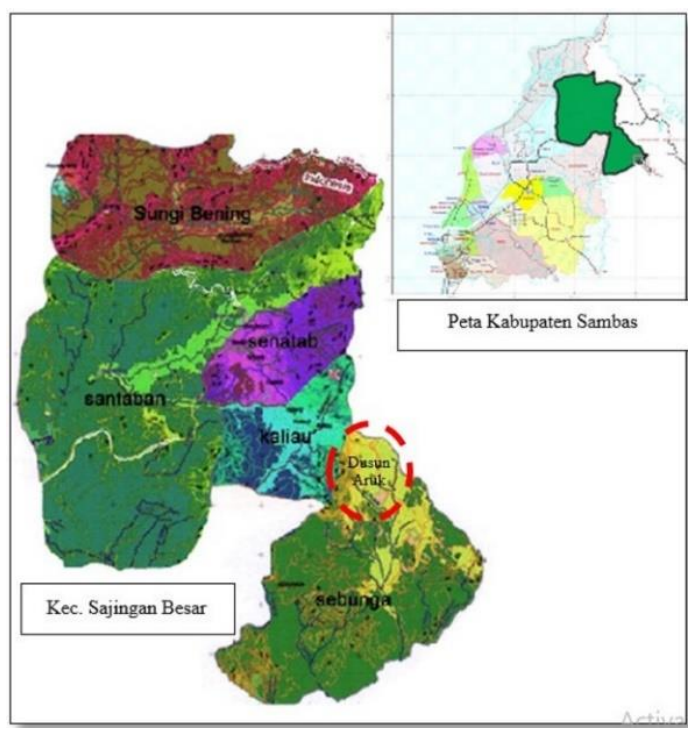

Gambar 1. Peta Lokasi Aruk diDesa Sebunga pa da Wilayah Kabupten Sambas

Sumber: (Badan Perencanaan Pembangunan Daerah, 2015) den gan modifikasi penulis 


\section{HASIL DAN PEMBAHASAN}

Penelitian ini difokuskan pada bangunanbangunan rumah tinggal yang dibangun oleh masyarakat secara mandiri dengan teknologi membangun yang dimiliki masyarakat setempat.

\subsection{Fungsi Bangunan}

Jika dilihat dari fungsinya, rumah tinggal yang berada di perbatasan dusun Aruk secara garis besar memiliki dua fungsi yaitu hunian (Gambar 2) dan fungsi hunian dengan fungsi tambahan komersil /ruko (Gambar 3).

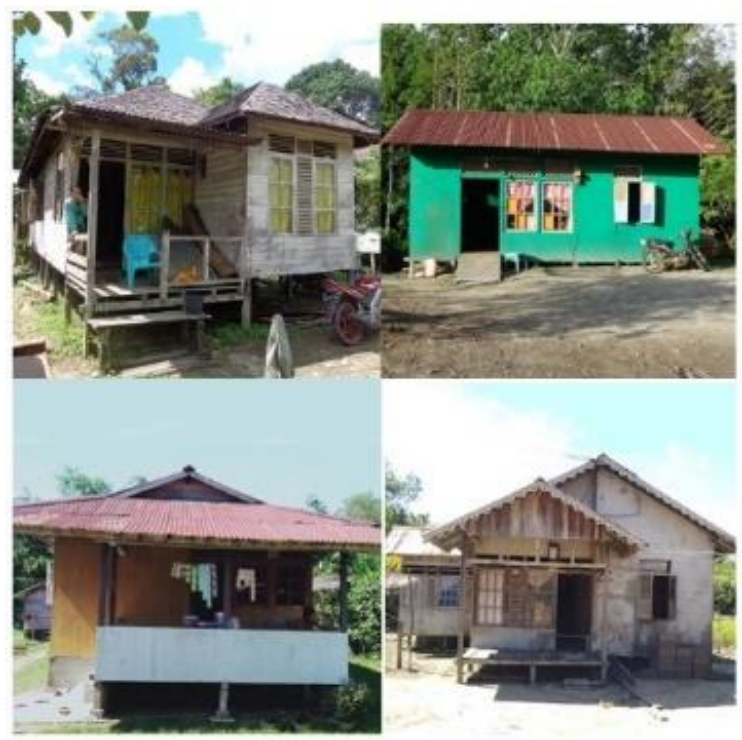

Gambar 2. Beberapa rumah yang berfungsi hanya sebagaihunian

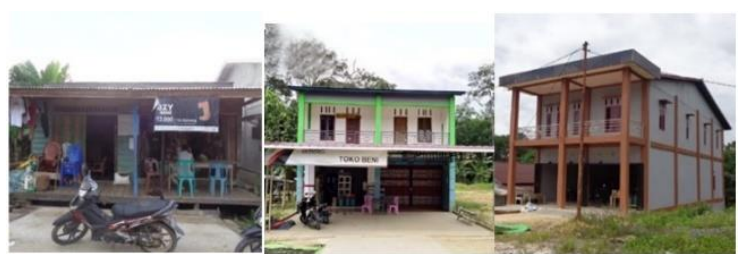

Gambar 3. Beberapa rumah tinggal dengan fungsi hunian sekaligus komersial

Rumah tinggal dengan fungsi hanya hunian memiliki persentasi paling besar. Hanya sekitar 9,46\% dari bangunan rumah tinggal juga difungsikan untuk kegiatan komersial (toko). Bangunan dengan tambahan fungsi komersial tersebut, jika dilihat dari tahun berdirinya, 44,44\% bangunan berdiri setelah tahun 2010 .

Jika dilihat berdasarkan luasan bangunan, terdapat berbagai variasi luasan yaitu berkisar
$24 \mathrm{~m}^{2}$ hingga $240 \mathrm{~m}^{2}$. Sedangkan jika dilihat dari jumlah penghuni/rumah, persentase yang paling banyak adalah 3 orang/ rumah atau dengan persentase $24.66 \%$. Berdasarkan nilai rata-rata luas bangunan dan nilai rata rata jumlah penghuni maka jumlah penghuni/ rumah adalah 4.356 atau 4 orang / rumah atau rata-rata luas hunian per orang adalah $19.25 \mathrm{~m}^{2} /$ orang.

\subsection{Material Bangunan}

Jenis konstruksi utama rumah tinggal kawasan dusun Aruk terbagi menjadi 2 yaitu kontruksi kayu dan beton seperti yang ditunjukkan pada Gambar 4 dan Gambar 5.

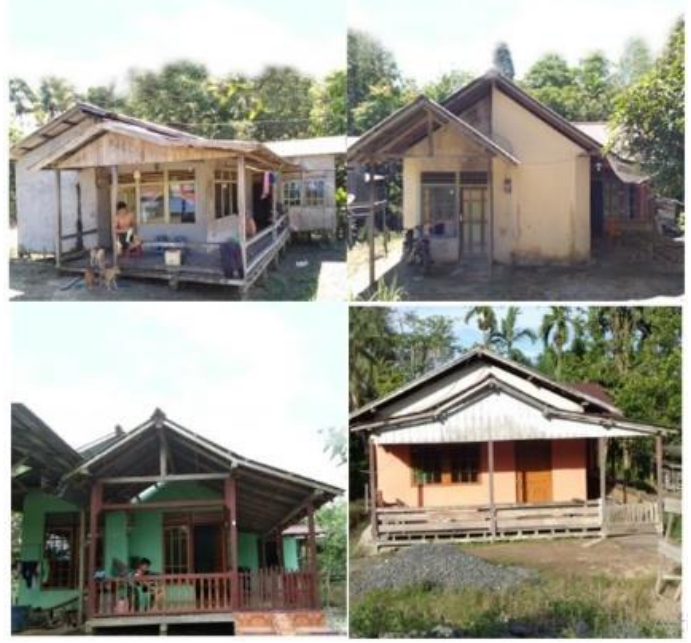

Gambar 4. Beberapa sampel ban gunan rumah tinggal yang menggunakan konstruksi u tama kayu

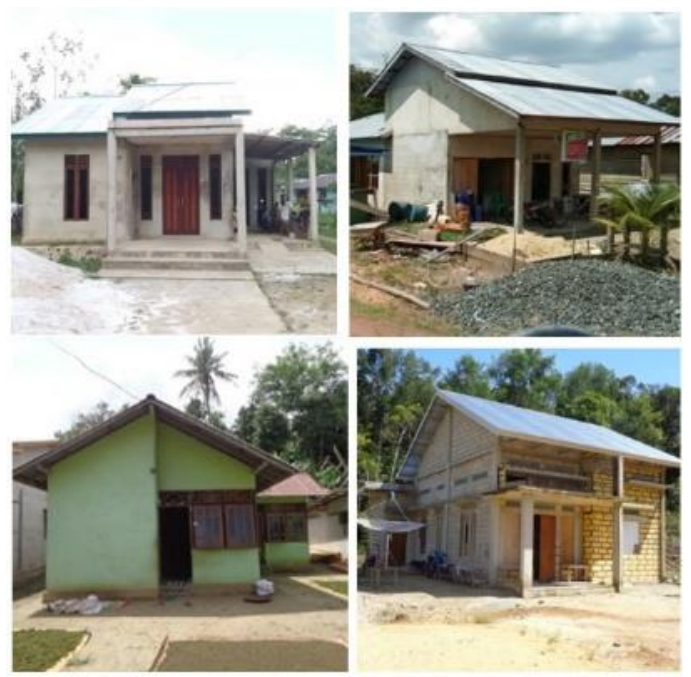

Gambar 5. Beberapa sampel rumah tinggal dengan konstruksiutama beton 
Sebagian besar bangunan menggunakan konstruksi kayu atau mencapai $72.97 \%$. Rumah tinggal yang menggunakan konstruksi utama beton hanya sekitar $27.03 \%$. Berdasarkan hasil analisis yang dilakukan, bangunan dengan konstruksi utama kayu cenderung digunakan pada bangunan-bangunan yang berdiri sebelum tahun 2000, sedangkan bangunan yang berdiri setelah tahun 2000 cenderung menggunakan konstruksi utama beton (Gambar 6).

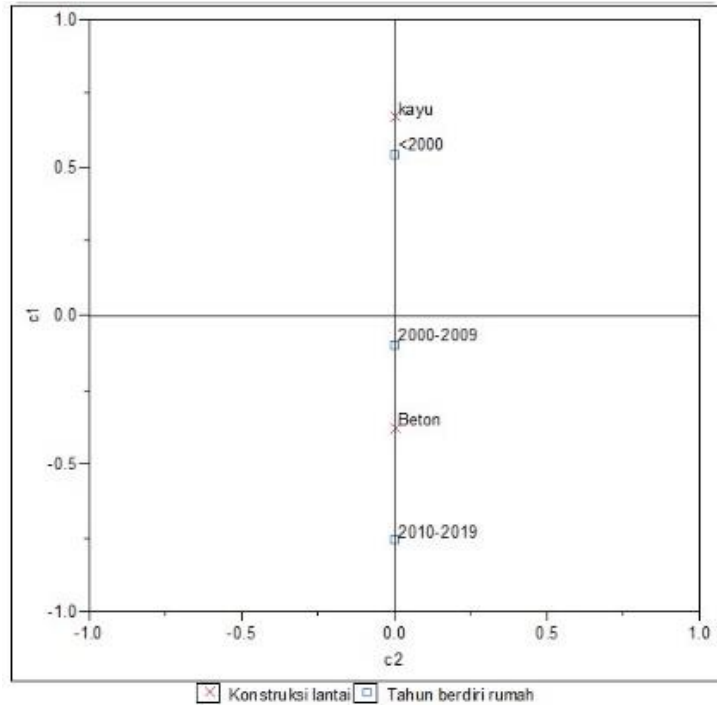

Gambar 6. Kedekatan data jenis konstruksi utama bangunan dengan tahun berdiri

Material konstruksi lantai yang digunakan pada bangunan tersebut terdiri dari 2 jenis yaitu konstruksi kayu (papan) dan beton. Kedua material konstruksi lantai yang digunakan tersebut ada yang menggunakan sistem lantai panggung dan ada pula yang menggunakan lantai lantai timbun. Hasil analisis yang dilakukan menunjukkan bahwa bangunan yang menggunakan sistem lantai panggung cenderung terdapat pada bangunan dengan konstruksi utama kayu, dan sebaliknya konstruksi utama beton cenderung menggunakan sistem lantai timbun. Jika dilihat dari tahun berdirinya bangunan, sistem lantai timbun cenderung digunakan pada bangunan yang berdiri di tahun 2010 ke atas (dapat di lihat pada Gambar 7). Hal ini juga menunjukkan bahwa bangunan yang awal berdiri merupakan bangunan dengan konstruksi utama kayu dengan lantai panggung.

Konstruksi dinding bangunan secara garis besar menggunakan 3 jenis material yaitu kayu/papan, batako dan simpai. Simpai adalah jenis dinding plesteran semen dengan menggunakan perkuatan anyaman kawat. Jenis kayu yang digunakan untuk kontruksi dinding papan sangat bervariasi.

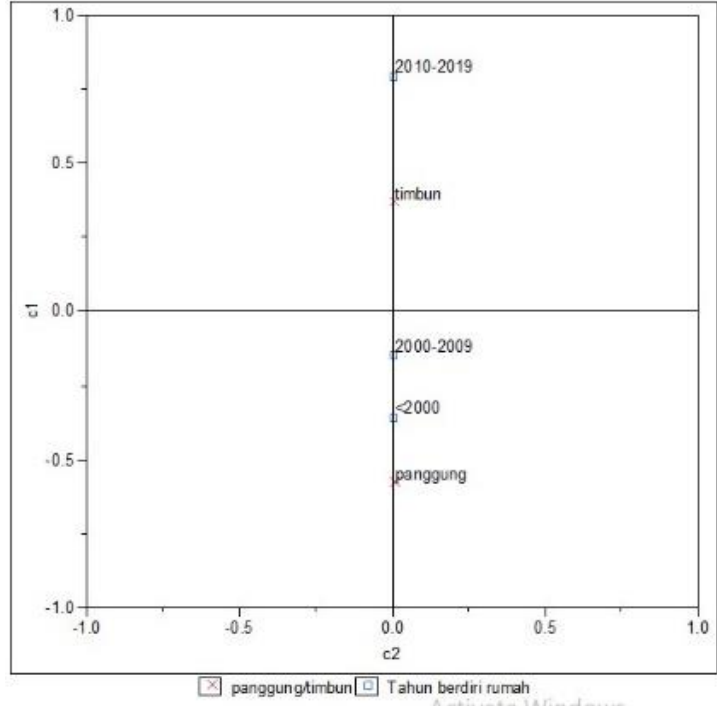

Gambar 7. Kedekatan data jenis sistem lantai bangunan dengan tahun berdiri

\subsection{Bentuk dan Tampilan Bangunan}

Karakteritik bentuk dan tampilan bangunan diidentifikasi berdasarkan bentuk atap, dinding, pintu dan jendela serta lubang angin. Rumah tinggal di kawasan dusun Aruk memiliki beberapa bentuk yang bervariasi. Bentuk atap yang ditemui di rumah-rumah dusun Aruk adalah bentuk atap sandar, atap perisai, atap pelana, serta atap campuran perisai dan pelana. Atap pelana sendiri digunakan dengan 2 tipe yaitu tipe bumbungan sejajar dengan sisi samping bangunan dan tipe bumbungan sejajar muka bangunan.

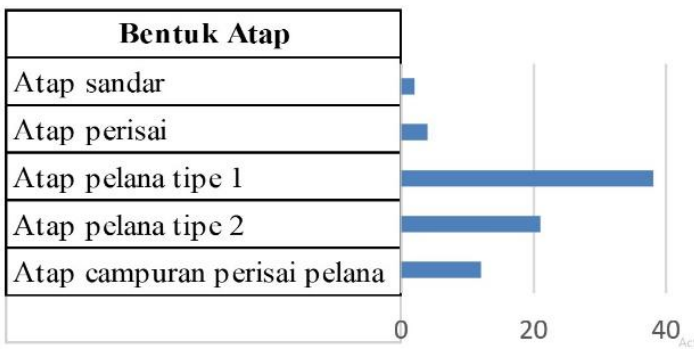

Gambar 8. Gra fik persentase penggunaan atap 


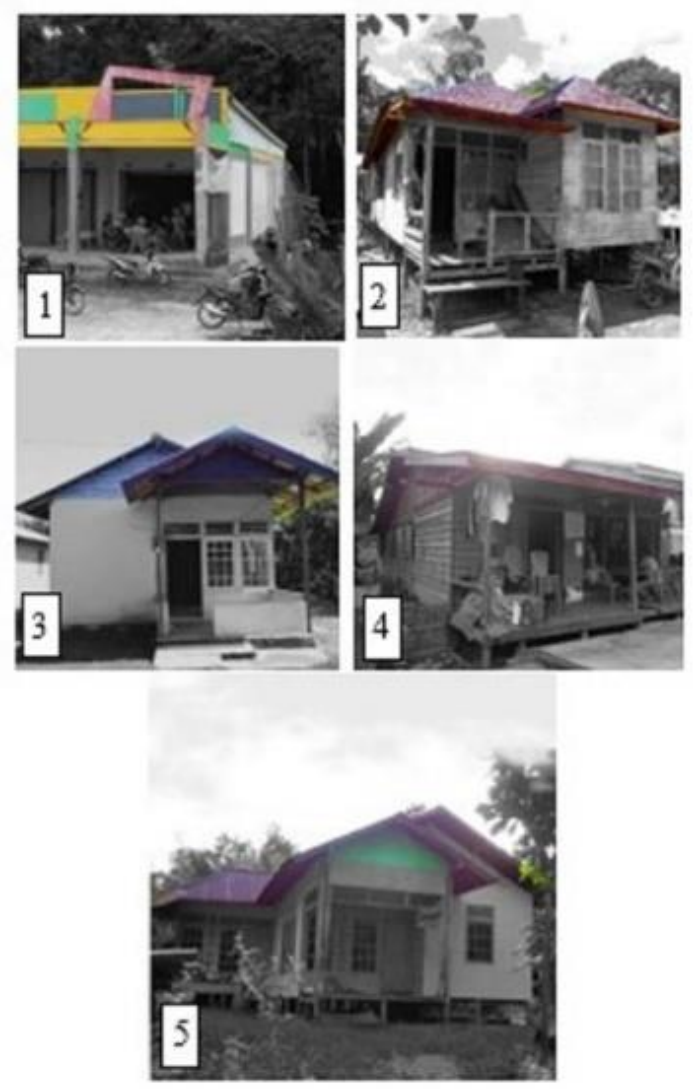

Gambar 9. Bentuk-bentuk a tap yang digunakan pada bangunan didaerah Aruk: (1) atap sandar, (2) atap perisai, (3) pelana tipe 1, (4) pela na tipe 2 dan

(5) campuran perisai dan pelana

Atap pelana merupakan bentuk yang paling banyak digunakan pada bangunan-bangunan tersebut seperti yang ditunjukkan pada Gambar 8. Gambar 9 menunjukkan bentuk-bentuk atap yang digunakan pada bangunan rumah di daerah Aruk.

Analisis terhadap bentuk atap yang digunakan terhadap tahun berdirinya bangunan rumah dapat dilihat pada Gambar 10. Gambar tersebut dapat menunjukkan bahwa bangunan dengan bentuk atap sandar cenderung digunakan pada bangunan yang berdiri di atas tahun 2000 . Hal ini juga terjadi pada jenis atap pelana tipe 2 . Jenis atap pelana tipe 1 , atap perisai dan atap campuran pelana perisai umumnya digunakan pada bangunan-bangunan yang berdiri lebih awal.

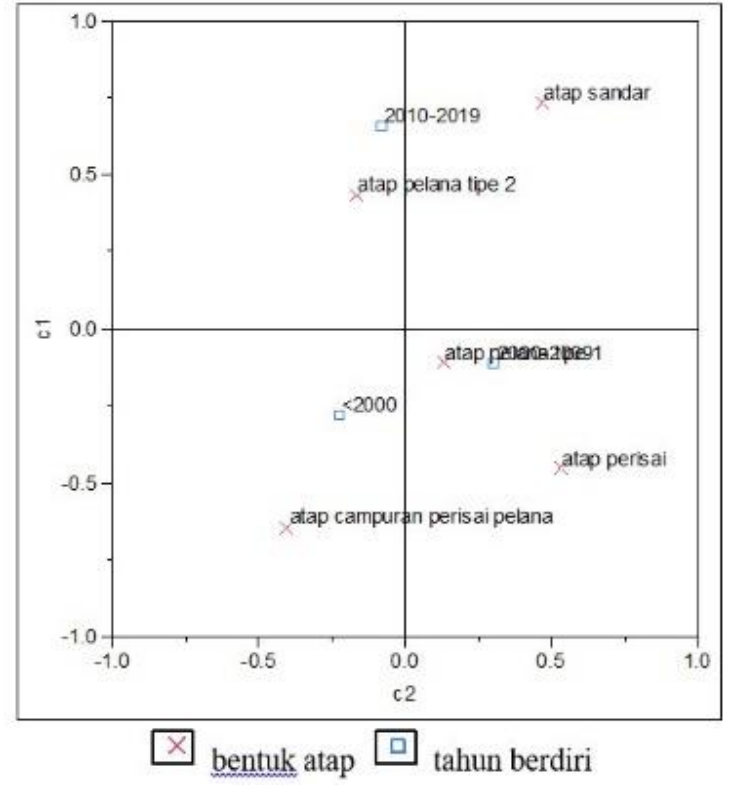

Gambar 10. Kedekatan data jenis bentuk a tap bangunan dengan tahun berdiri

Sebagaimana telah dipaparkan pada bagian material bangunan, terdapat 3 jenis dinding yang ditemui pada objek penelitian yaitu papan, batako dan simpai. Dinding dengan bahan papan memiliki 2 teknik penyusunan yaitu papan susun sirih dan papan susun alur dan lidah. Dinding dengan bahan batako terdapat 2 jenis yaitu dengan plester dan tanpa plester. Gambar 11 menunjukkan jenis-jenis dinding yang digunakan di daerah Aruk.

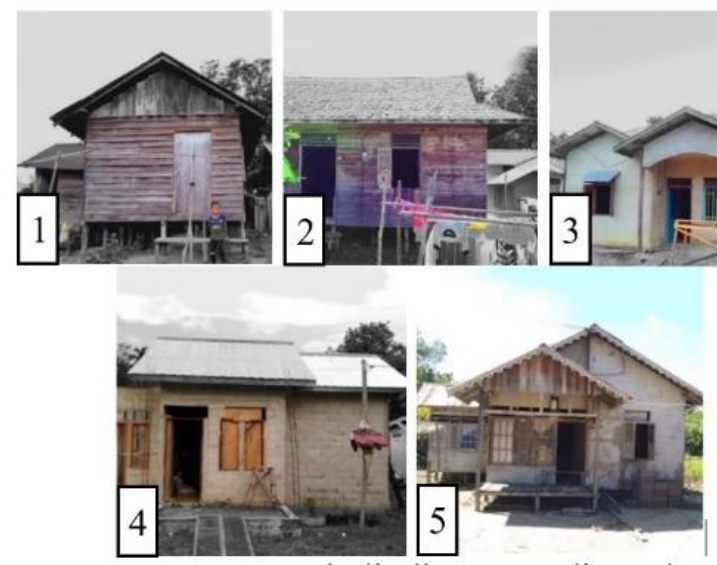

Gambar 11. Bentuk dinding yang digunakan pada bangunan di daerah Aruk: (1) pa pan su sun sirih, (2) papan susun alur dan lidah, (3) batako plester, (4) batakotanpa plester, dan (5) simpai 
Analisis terhadap jenis konstruksi dinding yang digunakan dengan tahun berdirinya bangunan rumah tersebut dapat dilihat pada Gambar 12. Gambar tersebut menunjukkan bahwa bangunan dengan konstruksi dinding batako baik yang diplester maupun yang tidak diplester lebih banyak digunakan pada bangunan yang berdiri setelah tahun 2000 sedangkan konstruksi dinding dengan material papan lebih banyak digunakan pada bangunan yang berdiri sebelum tahun 2000 .

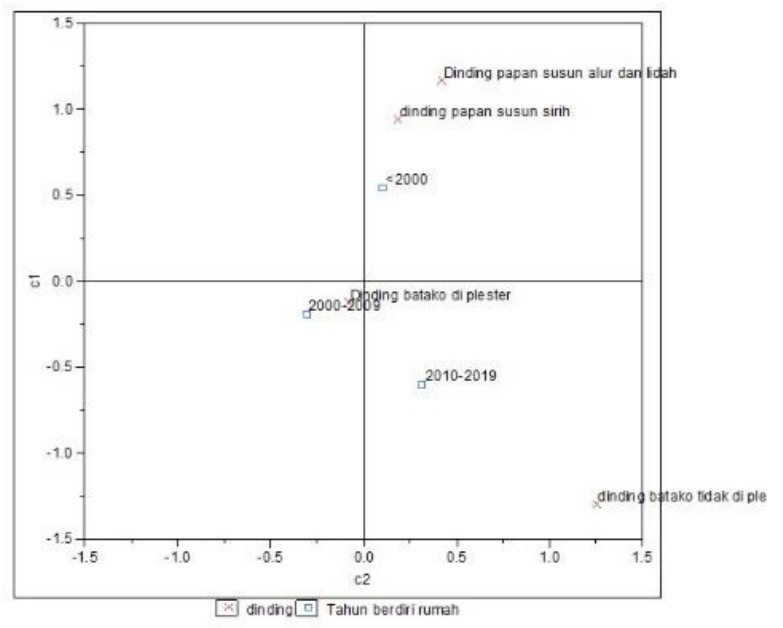

Gambar 12. Kedekatan data jenis konstruksi dinding bangunan dengan tahun berdiri

Jenis-jenis pintu yang digunakan pada rumah tinggal kawasan dusun Aruk antara lain pintu papan utuh, pintu panil, pintu multiplek, pintu jalusi/krepyak kayu dan pintu folding gate (Gambar 13). Sedangkan jenis jendela yang digunakan antara lain jendela kaca berdaun, jendela kaca naco, jendela jalusi/krepyak kayu, jendela panil, serta jendela papan (Gambar 14).
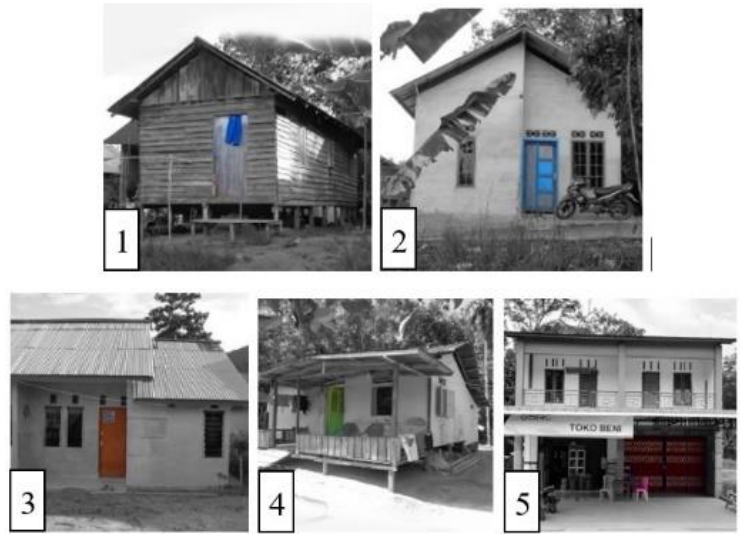

Gambar 13. Bentuk pintu yang digunakan pada bangunan di daerah Aruk: (1) pa pan, (2) panil kayu,
(3) multiplek, (4) jalusi/krepyak kayu dan(5)folding gate
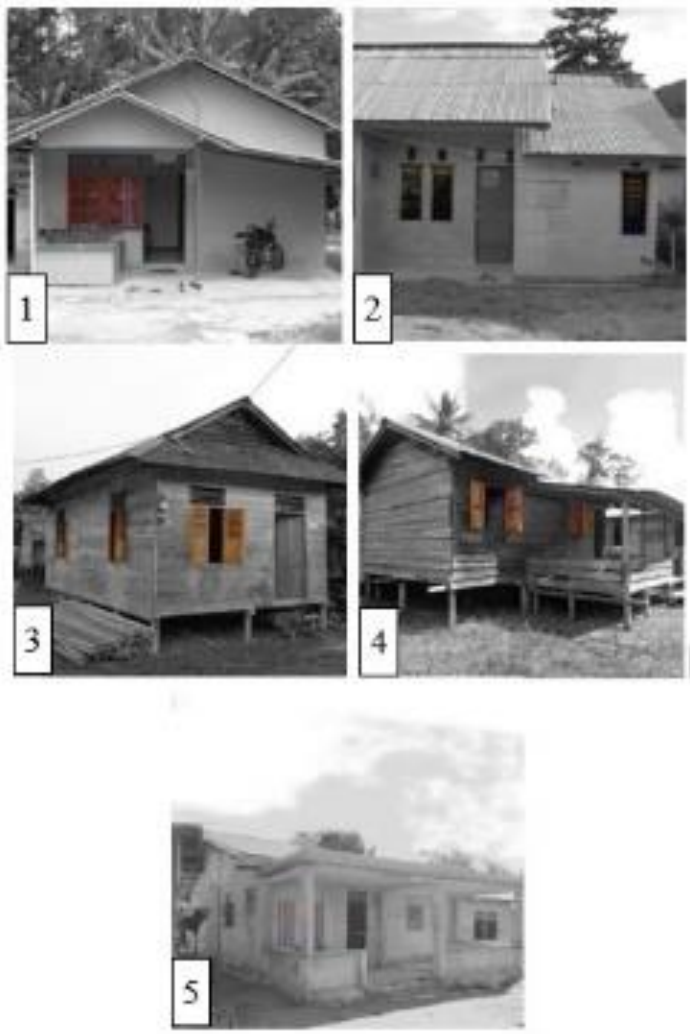

Gambar 14. Bentuk jendela yang digunakan pada bangunan didaerah Aruk; (1) kaca berdaun, (2) kaca naco, (3) ja lusi/krepyak kayu, (4) panil kayu dan (5) pa pan

Hubungan kedekatan antara jenis pintu dengan tahun berdirinya bangunan rumah menunjukkan bahwa hunian dengan pintu jenis folding gate dan multiplek muncul dan lebih dekat dengan bangunan yang berdiri setelah tahun 2010. Penggunakan jenis pintu lain dekat dengan rumah-rumah yang berdiri sebelum tahun 2010. Hubungan kedekatan antara jenis jendela dengan tahun berdirinya bangunan rumah tersebut dapat dilihat pada Gambar 15. Gambar tersebut menunjukkan bahwa hunian dengan jendela panil dan jendela krepyak kayu sebagian lebih dekat dengan bangunan yang berdiri sebelum tahun 2000. Sedangkan penggunakan jenis jendela kaca berdaun, kaca naco dan jendela papan tak teratur memiliki kedekatan dengan rumah-rumah yang berdiri pada tahun 2000 ke atas. 


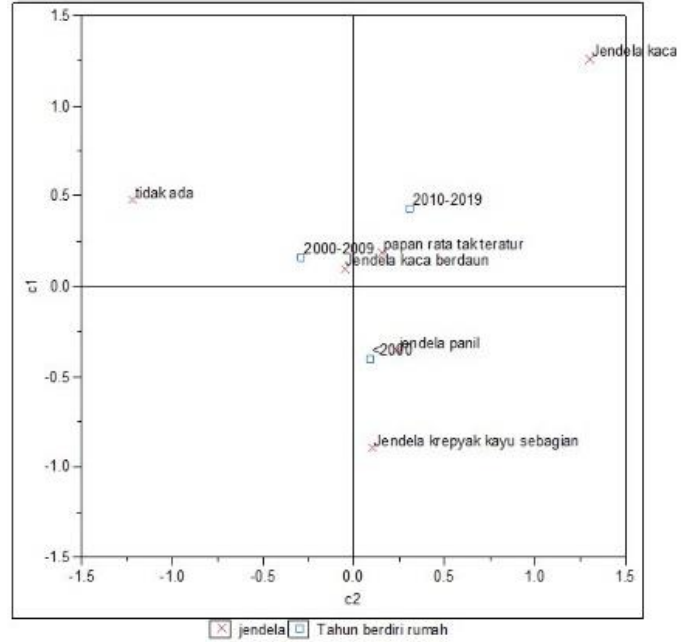

Gambar 15. Kedekatan data jenis jendela bangunan dan tahun berdiri

Jenis lubang angin yang digunakan pada bangunan-bangunan rumah di daerah Aruk dapat dikelompokkan menjadi kaca berdaun, glass block, kerawang, jalusi/krepyak kayu datar, profil kayu dan pelubangan dinding. Gambar jenis-jenis lubang angin tersebut dapat dilihat pada Gambar 16. Berdasarkan hasil analisis, jenis lubang angin yang digunakan tidak menunjukkan adanya kedekatan yang signifikan dengan jenis jendela atau pintu yang digunakan.

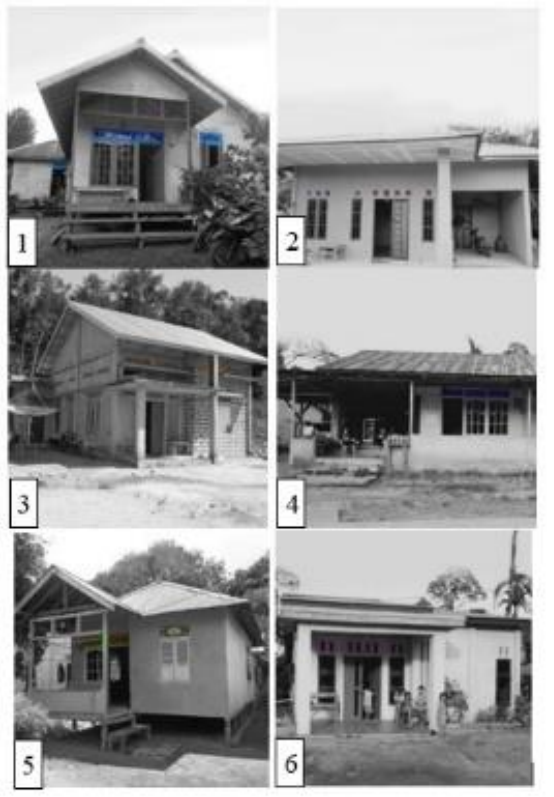

Gambar 16. Bentuk lubang angin y ang digunakan pada bangunan didaerah Aruk : (1) kaca berdaun, (2) glass block, (3) kerawang, (4) ja lusi/krepyak kayu datar, (5) profil kayu dan (6) pelubangan dinding.

\section{KESIMPULAN}

Karakteristik bangunan khususnya bangunan rumah pada kawasan perbatasan dusun Aruk pada penelitian ini dilihat dari fungsi bangunan, penggunaan material bangunan serta bentuk dan tampilan bangunan. Secara garis besar fungsi bangunan rumah terbagi menjadi 2 yaitu fungsi tempat tinggal dan fungsi tempat tinggal dengan tambahan fungsi komersil. Bangunan dengan fungsi tambahan komersil tidak terlalu besar jumlahnya dan muncul seiring dengan berkembangnya kawasan ini sebagai lalu lintas antar negara. Berdasarkan material konstruksi utama yang digunakan, bangunan rumah di dusun Aruk sebagian besar menggunakan konstruksi kayu atau mencapai $72.97 \%$ dari keseluruhan bangunan yang disurvey. Konstruksi utama lain yang digunakan adalah beton. Jika dilihat dari tahun berdirinya bangunan, konstruksi utama kayu cenderung digunakan pada bangunan-bangunan yang berdiri sebelum tahun 2000. Sedangkan bangunan yang berdiri setelah tahun 2000 lebih banyak menggunakan konstruksi utama beton. Hal ini juga terlihat dari material lantai dan dinding yang digunakan. Material papan dengan sistem panggung cenderung digunakan pada bangunan konstruksi kayu yang banyak berdiri sebelum tahun 2000, sedangkan lantai timbun beton cenderung digunakan pada bangunan dengan konstruksi utama beton dan banyak digunakan setelah tahun 2000. Konstruksi dinding rumah tinggal di kawasan Aruk secara garis besar menggunakan 3 jenis material yaitu kayu/papan, batako dan simpai. Ketiga jenis material dinding tersebut juga dapat dianalisis berdasarkan tahun berdirinya dimana konstruksi dinding batako baik yang diplester maupun yang tidak diplester lebih banyak digunakan pada bangunan yang berdiri setelah tahun 2000 sedangkan konstruksi dinding dengan material papan lebih banyak digunakan pada bangunan yang berdiri sebelum tahun 2000. Bentuk atap yang ditemui di rumah-rumah dusun Aruk antara lain atap sandar, atap perisai, atap pelana tipe 1 dan tipe 2 dan campuran perisai dan pelana. Jika dilihat dari tahun berdirinya bangunan, bentuk atap sandar dan pelana tipe 2 cenderung digunakan pada bangunan yang berdiri di atas tahun 2000 . Jenis atap pelana tipe 1 , atap perisai dan atap campuran pelana dan perisai umumnya 
digunakan pada bangunan-bangunan yang lebih awal berdirinya. Jenis-jenis pintu yang digunakan pada rumah tinggal di kawasan Aruk antara lain: pintu papan utuh, pintu panil, pintu multiplek, pintu jalusi/krepyak kayu dan pintu holding gate. Sedangkan jenis jendela yang digunakan antara lain: jendela kaca berdaun, jendela kaca naco, jendela jalusi/krepyak kayu, jendela panil, dan jendela papan. Jenis-jenis lubang angin yang digunakan antara lain lubang angin kaca berdaun, glass block, kerawang, jalusi/krepyak kayu datar, profil kayu dan pelubangan dinding.

Berbagai jenis material dan bentuk tampilan yang digunakan pada bangunan-bangunan rumah di kawasan Aruk mengalami perubahan jika dilihat dari tahun berdirinya bangunan. Material-material lokal dan mudah ditemukan di sekitar lokasi berupa kayu dengan sistem lantai panggung lebih banyak digunakan pada bangunan-bangunan yang berdiri lebih awal. Karakteristik ini mengalami perubahan dimana bangunan-bangunan yang lebih baru cenderung menggunakan material beton. Hal ini sejalan dengan semakin berkembangnya daerah dan semakin mudahnya akses menuju daerah tersebut. Tampilan pada bangunan juga mengalami pergeseran karakteristik dimana bangunan-bangunan yang lebih baru justru menggunakan tampilan yang lebih sederhana dan minim dekoratif. Dapat dilihat dari pemilihan bentuk atap, bangunan yang lebih lama justru memiliki bentuk atap yang lebih komplek dibandingkan bangunan yang lebih baru. Demikian pula dari pemilihan bentuk pintu, jendela dan lubang angin. Terjadi pergeseran karakteristik dimana pintu, jendela dan lubang angin bangunan-bangunan yang lebih baru cenderung menggunakan bentukbentuk yang lebih sederhana dengan material yang harus didatangkan dari luar lokasi seperti penggunaan pintu multiplek, jendela kaca dan pelubangan pada dinding sebagai lubang angin.

Perubahan ini menunjukkan adanya pergeseran karakteristik yang dimiliki oleh bangunanbangunan di daerah Aruk dilihat dari masa berdirinya. Pergeseran ini dikhawatirkan tidak disadari oleh masyarakat, sehingga karakter asli dapat hilang. Kondisi semakin terbukanya akses dan luasnya informasi dapat semakin memicu cepatnya perubahan yang dapat menghilangkan identitas yang dimiliki bangunan di kawasan tersebut. Perlu adanya upaya untuk mempertahankan karakter bangunan asli yang dapat meningkatkan kekuatan nilai identitas kawasan tersebut.

\section{UCAPAN TERIMAKASIH}

Penelitian ini dilakukan dengan dukungan pendanaan DIPA tahun 2019 dari Fakultas Teknik Universitas Tanjungpura. Ucapan terimakasih juga disampaikan kepada pihak Pemerintah Desa Sebunga khususnya Dusun Aruk, Kecamatan Sajingan Besar Kabupaten Sambas serta masyarakat setempat atas dukungannya dalam pengumpulan data penelitian ini.

\section{REFERENSI}

Arifin, R. (2010). Perubahan Identitas Rumah Tradisional Kaili Di Kota Palu. Jurnal Arsitektur, 2(1).

Badan Perencanaan Pembangunan Daerah, S. (2015). No Title.

Badan Pusat Statistik, K. S. (2019). Sajingan Besar Dalam Angka 2019 (K. S. Badan Pusat Statistik (ed.)). Badan Pusat Statistik Kabupaten Sambas. https://sambaskab.bps.go.id/publication

Dhika, V., \& Pm, N. (2012). Pengaruh Perkembangan Aktivitas Ekonomi Terhadap Struktur Ruang Kota Di SWP III Kabupaten Gresik. Teknik Perencanaan Wilayah Kota, 1(1), 76-86.

Firdaus, F. (2019). Dampak kebijakan pembangunan Pos Lintas Batas Negara (PLBN) Aruk di Desa Sebunga Kabupaten Sambas, Kalimantan Barat. Jurnal Ilmiah Ilmu Pemerintahan, 3(2), 109.

https://doi.org/10.14710/jiip.v3i2.3881

Heath, K. W. (2015). Assessing Regional Identity Amidst Change: The Role of Vernacular Studies. 13(2), 76-94.

Hidayatun, M. I., Prijotomo, J., \& Rachmawati, M. (2016). Vernacular architecture as an alternative design approach with interpretation of Paul Ricoeur's critical theory. A/Z ITU Journal of the Faculty of 
Architecture, 13(1), 107-114. https://doi.org/10.5505/itujfa.2016.65807

Januastuti, V., \& Artiningrum, P. (2018). Pengaruh Perubahan Fungsi Ruang Dan Bentuk Rumah-Toko Terhadap Karakteristik Arsitektur Cina Di Pecinan Pasar Lama Tangerang. Vitruvian, 8(1), 49.

https://doi.org/10.22441/vitruvian.2018.v $8 \mathrm{i} 1.006$

Jones, C., \& Svejenova, S. (2017). The Architecture of City Identities: A Multimodal Study of Barcelona and Boston. Research in the Sociology of Organizations, 54B(February), 203-234. https://doi.org/10.1108/S0733558X2017000054B007

Lestari, M., \& Suhadak. (2019). Pengaruh Pembangunan Infrastruktur Terhadap Pertumbuhan Ekonomi dan Pemerataan Ekonomi Indonesia. Jurnal Administrasi Bisnis, 70(1), 98-105.

Mufizar, Arkanudin, \& Achyar, M. S. (2012). Pembangunan Sosial Masyarakat Perbatasan di Kecamatan Sanjingan Besar Kabupaten Sambas Provinsi Kalimantan Barat. Jurnal PMIS, 1-22.

Murti, C., \& Wijaya, H. (2012). Pengaruh Kegiatan Komersial Terhadap Fungsi Bangunan Bersejarah Di Koridor Jalan Malioboro Yogyakarta. Teknik PWK (Perencanaan Wilayah Kota), 2(1), 6075.

Salman, M. (2016). Sustainability and Vernacular Architecture: Rethinking What Identity Is. In Urban and Architectural Heritage Conservation within Sustainability. https://doi.org/DOI: http://dx.doi.org/10.5772/intechopen.820 25

Suartha, N., \& Yasa, I. G. W. M. (2017). Pengaruh Pertumbuhan Ekonomi, Migrasi Masuk Terhadap Pertumbuhan Penduduk dan Alih Fungsi bangunan Penduduk Asli Kota Denpasar. Ekonomi Kuantitatif Terapan, 10(02), 95-107.

Sukwika, T. (2018). Peran Pembangunan Infrastruktur terhadap Ketimpangan Ekonomi Antarwilayah di Indonesia.
Jurnal Wilayah Dan Lingkungan, 6(2), 115. https://doi.org/10.14710/jwl.6.2.115-130

Torabi, Z., \& Brahman, S. (2013). Effective Factors in Shaping the Identity of Architecture. Middle East Journal of Scientific Research, 15(1), 106-113. https://doi.org/10.5829/idosi.mejsr.2013. 15.1.2357 